\title{
Human Neutrophil Elastase Inhibitory Alkaloids from Chelidonium majus L.
}

\author{
Jeong Yoon Kim · Ji Hye Lee • Yeong Hun Song • Won Min Jeong • Xuefei Tan • \\ Zia Uddin . Ki Hun Park* (D)
}

Received: 12 July 2015 / Accepted: 4 August 2015 / Published Online: 30 September 2015

(C) The Korean Society for Applied Biological Chemistry 2015

\begin{abstract}
Human neutrophil elastase (HNE) represents a good therapeutic target for the treatment of inflammatory diseases as well as invasion of microorganism. The methanol extract of a aerial part of Chelidonium majus L. showed high activity against the neutrophil elastase with an $\mathrm{IC}_{50}$ value of $100 \mu \mathrm{g} / \mathrm{mL}$. Due to its potency, subsequent bioactivity-guided fractionation of methanol extract led to six alkaloids (1-6), which were identified as dihydrosanguinarine (1), (s)-stylopine (2), arnottianamide (3), (+)-chelidonine (4), spallidamine (5), and $N$-transferuloyltyramine (6). Among of them, three alkaloids (2, 5, and 6) inhibited $\mathrm{HNE}$ in a dose-dependent manner with $\mathrm{IC}_{50}$ ranging between 11.6 and $51.0 \mu \mathrm{M}$. Lineweaver-Burk and Dixon plots, and their secondary replots showed that alkaloids $(\mathbf{2}, \mathbf{5}$, and $\mathbf{6})$ were mixed inhibitors of HNE. The analysis of $K_{\mathrm{I}}$ and $K_{\mathrm{IS}}$ value proved that all inhibitors $(\mathbf{2}, \mathbf{5}$, and $\mathbf{6})$ had reversible mixed type I mechanism.
\end{abstract}

Keywords Chelidonium majus L. · human neutrophil elastase · inflammation · isoquinoline alkaloid

\section{Introduction}

The regulation of the enzymatic activity of human neutrophil elastase (HNE) has been the attractive field because neutrophils

J. Y. Kim · J. H. Lee · Y. H. Song · W. M. Jeong $\cdot$ X. Tan · Z. Uddin · K. H. Park

Division of Applied Life Science (BK21 plus), IALS, Graduate School of Gyeongsang National University, Jinju 660-701, Republic of Korea

*Corresponding author (K. H. Park: khpark@gnu.ac.kr)

This is an Open Access article distributed under the terms of the Creative Commons Attribution Non-Commercial License (http://creativecommons. org/licenses/by-nc/3.0/) which permits unrestricted non-commercial use, distribution, and reproduction in any medium, provided the original work is properly cited. are the first cells recruited to inflammatory sites and from the earliest line of defense against the invasion of microorganism (Brice et al., 2010). The human neutrophil elastase (EC 3. 4. 21. 37 ) is the family of serine proteases that possess the ability to hydrolyze the extracellular matrix protein (Siedle et al., 2007). It is present in azurophil granules in the neutrophil cytoplasm. HNE is a proteolytic enzyme involved in pathogenesis of emphysema, adult respiratory distress syndrome and rheumatoid arthritis (Crocetti et al., 2013). The catalytic site of HNE molecule is composed of the triad His41-Asp99-Ser173, of which the oxygen of serine attacks carbonyl group on the target substrate (Bode et al., 1989). The activity of HNE is controlled by inhibitor named $\alpha 1$-antitrypsin produced in the liver. However, their HNE affinity is strongly decreased by oxidative stress and by proteases released from leukocytes that are recruited to inflammation sites (Brice et al., 2010). Thus, the imbalance between HNE and its inhibitors is implicated in many inflammation diseases as like pulmonary emphysema.

Chelidonium majus L. is a perennial herbaceous plant of the family Papaveraceae, which is widely distributed around the world. This plant has been traditionally used as an herbal medicine for treatment of gastric ulcer, oral infection and liver disease (Lenfield et al., 1981). These effects are mainly due to the alkaloids present in milk sap. The major bioactive components of this plant are isoquinoline alkaloids such as chelidonine, chelerythrine, sanguianarine, bebeerine and coptisine (Barreto et al., 2003). It included flavonoids and various acids such as ferulic, cumaric, caffeic and chelidonic acids (Barens J et al., 2007). The constituents of C. majus L. have been found to exhibit antitumor, antiviral, and anti-inflammatory activities (Colombo and Bosisio, 1996). Additionally, the potent and selective acetylcholinesterase inhibition was observed on 8-hydroxydihydrochelerythrine in C. majus $\mathrm{L}$ (Cho et al., 2006).

During a screening procedure on higher plant to find neutrophil elastase inhibitors, methanol extract of C. majus L. was shown to exhibit considerable inhibitory activity. In this study, we isolated six alkaloids targeting to HNE from the methanol extract of aerial 
portion of $C$. majus L. The isolated compounds were evaluated separately for their inhibitory activities against HNE. Their inhibition mechanism was ascertained using Lineweaver-Burk and Dixon plots. The literature revealed that no such work has been reported on the $C$. majus $\mathrm{L}$.

\section{Materials and Methods}

Chemicals and Instruments. $1 \mathrm{D}$ and 2D NMR spectra were obtained using a Bruker AM-500 spectrometer $(300,500 \mathrm{MHz}$ for ${ }^{1} \mathrm{H}, 75,125 \mathrm{MHz}$ for ${ }^{13} \mathrm{C}$ ) in $\mathrm{CDCl}_{3}$ or DMSO- $d_{6}$ with TMS as internal standard. ESIMS data and HRESIMS data were recorded on a JEOL JMS-700 mass spectrometer (JEOL, Japan). Enzymatic assays were carried out on a SpectraMaxM $\mathrm{M}_{3}$ Multi-Mode Microplate Reader (Molecular Devise, USA). Column chromatographies were performed using silica gel (230-400 mesh, Merck Co., Germany), Octadecylsilanized (ODS) silica gel $(50 \mu \mathrm{m}$, YMC Ltd, Japan) and Sephadex LH-20 (50 $\mu \mathrm{m}$, Amersham Pharmacia Biotech, Sweden). Fractions were monitored by precoated silica gel $60 \mathrm{~F}_{254}$ plates $(0.25 \mathrm{~mm}$, Merck), and spots were visualized by spraying with $10 \%$ sulfuric acid solution followed by heating. Ursolic acid was purchased from Sigma-Aldrich (USA). All solvents used for extraction and isolation were of analytical grade. C. majus was purchased from the local market and stored at a freezer before use.

Plant material, extraction and isolation. The dried aerial part of C. majus L. (1 kg) was purchased from local market extracted with methanol $(18 \mathrm{~L})$ two times at room temperature. The methanol soluble portion was concentrated to give the crude extract $(96 \mathrm{~g})$, which was portioned between $\mathrm{H}_{2} \mathrm{O}$ and $n$-hexane. The aqueous layer was further partitioned with EtOAc to give the EtOAc extract (32 g), which was subjected to MPLC (PuriFlash ${ }^{\circledR}$ 450, Interchim, France) on silicagel with a gradient solvent system $\left(\mathrm{CHCl}_{3}-\mathrm{MeOH}=50: 1\right.$ to $\left.10: 1\right)$ to give four fractions (A-D). Potent inhibition targeting to neutrophil elastase was found on faction $B$ that was further chromatographed on a silicagel column with a gradient solvent system ( $n$-hexane-EtOAc $=100: 0$ to $1: 1)$ to give fifteen fractions (Fr1-Fr15). The Fr2 was purified by silicagel column with a gradient solvent system ( $n$-hexane-acetone $=100: 1$ to $1: 1$ ) to yield arnottianamide ( $37 \mathrm{mg}, 3$ ). Fr4 was chromatographed on a sephadex LH-20 column with methanol as the eluent to give nine main fractions (Fr6-1-Fr6-9). Fr6-7 was purified by ODS column chromatography with $80 \% \mathrm{MeOH}$ as the eluent to give dihydrosanguinarine (23 mg, 1) and (s)-stylopine (41 mg, 2). Fr68 was purified on a sephadex LH-20 column with $\mathrm{MeOH}$ as eluent to give (+)-chelidonine $(19 \mathrm{mg}, 4)$. Fr7 was purified by ODS column chromatography with $80 \% \mathrm{MeOH}$ as the eluent to give spallidamine (28 mg, 5) and $N$-trans-feruloyltyramine $(56 \mathrm{mg}$, 6). The chemical structures of these compounds were determined by comparison of their spectroscopic data with those previously reported (Ma et al., 1999; Koul et al., 2002; Kanada et al., 2012). Dihydrosanguinarine (1): white powder; $\mathrm{mp} 185-188^{\circ} \mathrm{C}$; EIMS, $m / z 333[\mathrm{M}]^{+}$; HREIMS, $m / z 333.1004$ (calcd for $\mathrm{C}_{20} \mathrm{H}_{15} \mathrm{NO}_{4}$
333.3374); ${ }^{1} \mathrm{H}-\mathrm{NMR}\left(\mathrm{CDCl}_{3}, 300 \mathrm{MHz}\right) \delta 7.68(1 \mathrm{H}, \mathrm{d}, J=8.6$ $\mathrm{Hz}), 7.67(1 \mathrm{H}, \mathrm{s}), 7.47(1 \mathrm{H}, \mathrm{d}, J=8.6 \mathrm{~Hz}), 7.26(1 \mathrm{H}, \mathrm{d}, J=8.1$ $\mathrm{Hz}), 7.10(1 \mathrm{H}, \mathrm{s}), 6.85(1 \mathrm{H}, \mathrm{d}, J=8.1 \mathrm{~Hz}), 6.04(2 \mathrm{H}, \mathrm{s}), 6.03(2 \mathrm{H}$, s), $4.19(2 \mathrm{H}, \mathrm{s}), 2.61(3 \mathrm{H}, \mathrm{s})$.

(s)-stylopine (2): yellow powder; $[\alpha]_{\mathrm{D}}+82\left(\mathrm{C} 0.45, \mathrm{CHCl}_{3}\right) ; \mathrm{mp}$ 198-202 ${ }^{\circ} \mathrm{C}$; EIMS, $m / z 323$ [M] ${ }^{+}$; HREIMS, $m / z 323.1158$ (calcd for $\left.\mathrm{C}_{19} \mathrm{H}_{17} \mathrm{NO}_{4} 323.34\right)$; ${ }^{1} \mathrm{H}-\mathrm{NMR}\left(\mathrm{CDCl}_{3}, 300 \mathrm{MHz}\right) \delta 6.75(1 \mathrm{H}$, s), $6.71(1 \mathrm{H}, \mathrm{d}, J=7.9 \mathrm{~Hz}), 6.66(1 \mathrm{H}, \mathrm{d}, J=8.0 \mathrm{~Hz}), 6.62(1 \mathrm{H}, \mathrm{s})$, $5.98(1 \mathrm{H}, \mathrm{s}), 5.95(1 \mathrm{H}, \mathrm{s}), 5.94(2 \mathrm{H}, \mathrm{s}), 4.12(1 \mathrm{H}, \mathrm{d}, J=15.3 \mathrm{~Hz})$, 3.60 (1H, br s), 3.57 (1H, br s), $3.26(1 \mathrm{H}, \mathrm{dd}, J=16.0,3.46 \mathrm{~Hz})$, $3.16(2 \mathrm{H}, \mathrm{m}), 2.83(1 \mathrm{H}, \mathrm{t}, J=28.0,15.5,11.6 \mathrm{~Hz}), 2.67(2 \mathrm{H}, \mathrm{m})$. Arnottianamide (3): ivory crystal; EIMS, $\mathrm{m} / \mathrm{z} 381$ [M] ${ }^{+}$; HREIMS, $\mathrm{m} / \mathrm{z} 381.1212$ (calcd for $\mathrm{C}_{21} \mathrm{H}_{19} \mathrm{NO}_{6} 381.3787$ ); ${ }^{1} \mathrm{H}-\mathrm{NMR}\left(\mathrm{CDCl}_{3}\right.$, $300 \mathrm{MHz}) \delta 8.09(1 \mathrm{H}, \mathrm{s}), 7.66(1 \mathrm{H}, \mathrm{d}, J=8.7 \mathrm{~Hz}), 7.24(1 \mathrm{H}, \mathrm{d}$, $J=8.3 \mathrm{~Hz}), 7.13(1 \mathrm{H}, \mathrm{s}), 7.01(1 \mathrm{H}, \mathrm{s}), 6.73(1 \mathrm{H}, \mathrm{d}, J=8.6 \mathrm{~Hz})$, $6.47(1 \mathrm{H}, \mathrm{d}, J=8.6 \mathrm{~Hz}), 6.01(2 \mathrm{H}, \mathrm{s}), 3.94(3 \mathrm{H}, \mathrm{s}), 3.83(3 \mathrm{H}, \mathrm{s})$, $2.93(3 \mathrm{H}, \mathrm{s})$.

(+)-Chelidonine (4): ivory crystal; $[\alpha]_{\mathrm{D}}-319\left(\mathrm{C} 0.50, \mathrm{CHCl}_{3}\right) ; \mathrm{mp}$ 136- $138^{\circ} \mathrm{C}$; EIMS, $m / z 353$ [M] $]^{+}$; HREIMS, $m / z$ 353.1266 (calcd for $\left.\mathrm{C}_{20} \mathrm{H}_{21} \mathrm{NO}_{5} 353.3844\right)$; ${ }^{1} \mathrm{H}-\mathrm{NMR}\left(\mathrm{CDCl}_{3}, 300 \mathrm{MHz}\right) \delta 6.77$ $(1 \mathrm{H}, \mathrm{s}), 6.68(1 \mathrm{H}, \mathrm{s}), 6.66(1 \mathrm{H}, \mathrm{s}), 5.97(1 \mathrm{H}, \mathrm{d}, J=4.3 \mathrm{~Hz}), 5.95$ $(2 \mathrm{H}, \mathrm{t}, J=3.2,1.5 \mathrm{~Hz}), 5.01(1 \mathrm{H}, \mathrm{d}, J=1.4 \mathrm{~Hz}), 4.26(1 \mathrm{H}, \mathrm{br} \mathrm{s})$, $4.11(1 \mathrm{H}, \mathrm{d}, J=15.6 \mathrm{~Hz}), 3.59(1 \mathrm{H}, \mathrm{br} \mathrm{s}), 3.45(1 \mathrm{H}, \mathrm{d}, J=15.6$ $\mathrm{Hz}), 3.25$ (1H, d, $J=17.6 \mathrm{~Hz}), 3.08$ (1H, dd, J =17.5, 4.4 Hz), 2.98 $(1 \mathrm{H}, \mathrm{t}, J=2.5 \mathrm{~Hz}), 2.30(3 \mathrm{H}, \mathrm{s})$.

Spallidamine (5): yellow powder; $[\alpha]_{\mathrm{D}}+17\left(\mathrm{C} 0.45, \mathrm{CHCl}_{3}\right)$; EIMS, $m / z 391\left[\mathrm{M}^{+}\right.$; HREIMS, $m / z 391.1056$ (calcd for $\mathrm{C}_{18} \mathrm{H}_{19} \mathrm{NO}_{4}$ 391.3735); ${ }^{1} \mathrm{H}-\mathrm{NMR}\left(\mathrm{CDCl}_{3}, 500 \mathrm{MHz}\right) \delta 7.70(1 \mathrm{H}$, d, $J=8.5 \mathrm{~Hz}), 7.58(1 \mathrm{H}, \mathrm{d}, J=8.5 \mathrm{~Hz}), 7.41(1 \mathrm{H}, \mathrm{s}), 7.35(1 \mathrm{H}, \mathrm{d}$, $J=8.0 \mathrm{~Hz}), 7.14(1 \mathrm{H}, \mathrm{s}), 6.91(1 \mathrm{H}, \mathrm{d}, J=8.0 \mathrm{~Hz}), 6.08(2 \mathrm{H}, \mathrm{s})$, $6.06(2 \mathrm{H}, \mathrm{s}), 4.69(1 \mathrm{H}, \mathrm{t}, J=7.5 \mathrm{~Hz}, \mathrm{H}-6), 2.79\left(3 \mathrm{H}, \mathrm{s}, \mathrm{N}-\mathrm{CH}_{3}\right)$, $2.45(2 \mathrm{H}, \mathrm{d}, J=7.5 \mathrm{~Hz})$.

$N$-trans-feruloyltyramine (6): ivory crystal; EIMS, m/z $313[\mathrm{M}]^{+}$; HREIMS, $m / z 313.1315$ (calcd for $\mathrm{C}_{18} \mathrm{H}_{19} \mathrm{NO}_{4} 313.3478$ ); ${ }^{1} \mathrm{H}-$ NMR $\left(\mathrm{CDCl}_{3}, 500 \mathrm{MHz}\right) \delta 7.33(1 \mathrm{H}, \mathrm{d}, J=15.1 \mathrm{~Hz}), 7.01(1 \mathrm{H}$, $\mathrm{d}, J=1.5 \mathrm{~Hz}), 6.96(1 \mathrm{H}, \mathrm{s}), 6.94(1 \mathrm{H}, \mathrm{s}), 6.92(1 \mathrm{H}, \mathrm{dd}, J=8.7,18.1$ $\mathrm{Hz}), 6.69(1 \mathrm{H}, \mathrm{d}, J=13.7 \mathrm{~Hz}), 6.30(1 \mathrm{H}, \mathrm{d}, \mathrm{J}=15.1 \mathrm{~Hz}), 6.63(1 \mathrm{H}$, $\mathrm{s}, J=8.5 \mathrm{~Hz}), 6.61(1 \mathrm{H}, \mathrm{s}), 3.77(3 \mathrm{H}, \mathrm{s}), 3.36(3 \mathrm{H}, \mathrm{t}, J=13.7,28.0$ $\mathrm{Hz}), 2.65$ (2H, t, $J=13.6,28.0 \mathrm{~Hz})$.

Measurement of neutrophil elastase activity. Human neutrophil elastase (EC 3. 4. 21. 37) (Sigma-Aldrich) was assayed as described previously with slight modification (Johansson et al., 2002), using succinyl-Ala-Ala-Ala- $p$-nitroaniline (Bachem., USA) as substrate. In spectrophotometric experiments, enzyme activity [initial velocity $\left(v_{\mathrm{i}}\right)$ ] was monitored by observing the hydrolysis of p-nitroaniline at $405 \mathrm{~nm}$. All samples were dissolved in 100\% DMSO at $200 \mu \mathrm{M}$ stock concentrations and used for the experiment with dilution. The mixture contained $130 \mu \mathrm{L} 0.02 \mathrm{mM}$ Tris- $\mathrm{HCl}$ buffer solutions ( $\mathrm{pH} 8.0)$ and $20 \mu \mathrm{L}$ enzymes $(0.02 \mathrm{Unit} / \mathrm{mL})$ were preincubated for $10 \mathrm{~min}$ in the presence of test compounds or vehicle (DMSO). The final concentration of DMSO was 5\% throughout. The reaction was started by the addition of $40 \mu \mathrm{L}$ substrate (1.5 mM Suc-Ala-Ala-Ala- $p$ NA). The percent inhibition ratio (percent) was calculated according to the following equation: 
<smiles>CN1Cc2c(ccc3c2OCO3)-c2ccc3cc4c(cc3c21)OCO4</smiles>

1<smiles>CN1Cc2c(ccc3c2OCO3)[C@@H]2[C@@H](O)Cc3cc4c(cc3[C@@H]21)OCO4</smiles>

4<smiles>c1cc2c(c3c1CC1c4cc5c(cc4CCN1C3)OCO5)OCO2</smiles>

2<smiles>CN1c2c(ccc3cc4c(cc23)OCO4)-c2ccc3c(c2C1CC(=O)O)OCO3</smiles>

5<smiles>COc1ccc(-c2ccc3cc4c(cc3c2N(C)C(C)=O)OCO4)c(O)c1OC</smiles>

3<smiles>COc1ccc(/C=C/C(=O)NCCc2ccc(O)cc2)cc1O</smiles>

6

Fig. 1 Chemical structures of alkaloids (1-6) from Chelidonium majus L.

$\%$ inhibition $=[$ (rate of control reaction - rate of sample reaction $) /$ rate of control reaction] $\times 100$

Enzyme kinetic assay and progress linear determination. Compounds $(\mathbf{2}, \mathbf{5}$, and $\mathbf{6})$ showing the highest inhibitory activities were further characterized by the assay conditions. The inhibition kinetics of human neutrophil elastase by the compounds $(\mathbf{2}, \mathbf{5}$, and 6) was analyzed by Lineweaver-Burk plots and compared to data obtained in the absence of inhibitors. Kinetic parameters associated with inhibition mechanism of HNE, steady-state rates were obtained at several inhibitor concentrations. The two inhibition constants for inhibitor binding with either free or enzymesubstrate complex, $K_{\mathrm{I}}$ or $K_{\mathrm{IS}}$, were obtained from secondary plots of the slopes of the straight lines or vertical intercept, respectively, versus the concentration of inhibitors. The constants for inhibitor binding with free or enzyme-substrate complex, $K_{\mathrm{I}}$ or $K_{\mathrm{IS}}$ with Suc-Ala-Ala-Ala- $p$ NA as substrate, were obtained from the second plots of the slopes of the straight lines or vertical intercept $\left(1 / V_{\max }^{a p p}\right)$, versus the concentration of inhibitors. The data were analyzed using the a nonlinear regression program [Sigma Plot (SPCC Inc., USA)] to give the individual parameters for each curve. The parameters are represented by Eqs.: (1)-(3) (Zhang et al., 2006; Chiari et al., 2011):

$$
\begin{aligned}
& \left.1 / V=K_{\mathrm{m}} / V_{\max }\left(1+[\mathrm{I}] / K_{\mathrm{I}}\right) 1 / \mathrm{S}+1 / V_{\max }\right) \\
& \text { Slope }=K_{\mathrm{m}} / K_{\mathrm{I}} V_{\max }[\mathrm{I}]+K_{\mathrm{m}} / V_{\max } \\
& \text { Intercept }=1 / K_{\mathrm{IS}} V_{\max }[\mathrm{I}]+1 / V_{\max }
\end{aligned}
$$

\section{Results and Discussion}

Structural identification of human neutrophil elastase inhibitors. In the preliminary study, we confirmed human neutrophil elastase inhibitory activity of methanol extract of $C$. majus. The methanol extract exhibited $88 \%$ inhibition at $100 \mu \mathrm{g} / \mathrm{mL}$. The high potency of the methanol extract encouraged us to identify the compounds responsible for its human neutrophil elastase inhibition. The six alkaloids (1-6) in Fig. 1 were isolated from methanol extract of $C$. majus L. by chromatography over silicagel, sephadex LH-20 and octadecyl functionalized silicagel, compounds (1-6) were identified as dihydrosanguinarine (1), (s)-stylopine (2), arnottianamide (3), (+)-chelidonine (4), spallidamine (5), and $\mathrm{N}$-trans-feruloyltyramine (6) by comparing their spectroscopic data of those previously reported (Ma et al., 1999; Kanada et al., 2012). The representative quinolone (spallidamine, 5) was isolated as a yellow powder with molecular formula $\mathrm{C}_{22} \mathrm{H}_{17} \mathrm{NO}_{6}$ established by the $\left[\mathrm{M}^{+}\right]$ion at 391.1056 (Calcd 391.3755) in HREIMS. ${ }^{1} \mathrm{H}$ and ${ }^{13} \mathrm{C}$ NMR in conjunction with DEPT experiments indicated the presence of 22 carbons consistency of the following functional groups: 7 methines $\left(\mathrm{sp}^{2}\right), 3$ methylenes $\left(\mathrm{sp}^{3}\right), 1$ methyl and 11 quanternary carbons. The ${ }^{13} \mathrm{C}$ NMR data enabled carbons corresponding to the $8 \mathrm{C}-\mathrm{C}$ double bonds and 1 carbonyl group to be identified and thus accounted for 9 of 15 degrees of unsaturation. The extra six degrees of unsaturation were ascribed to six rings, three of which were aromatics. The existence of two methylenedioxy groups was revealed by the signals at $\delta_{\mathrm{H}} 6.08(d, 4 \mathrm{H})$. Analysis of spectroscopic data and comparison of previous data showed compound 5 to be spallidamine (Ma et al., 1999).

Human neutrophil elastase inhibitory activity. Human neutrophil elastase is considered to be the primary source of tissue damage associated with many inflammatory diseases. The isolated alkaloids (1-6) were screened for their in vitro human neutrophil elastase (EC 3. 4. 21.37) inhibitory activities at different concentration by using succinyl-Ala-Ala-Ala- $p$-nitroaniline as substrate. As shown in Fig. 2A all compounds exhibited a dose-dependent inhibitory effect on the HNE. But among of them, two isoquinolines ( 2 and 5) and cinnamicamide (6) appreciably inhibited HNE activity with $\mathrm{IC}_{50}$ ranging between 11.6 and $51.0 \mu \mathrm{M}$ (Table 1). The inhibition of $\mathrm{HNE}$ by compound $\mathbf{5}$, the most potent inhibitor $\left(\mathrm{IC}_{50}=11.6\right.$ $\mu \mathrm{M})$ is illustrated in Fig. 2B, representatively. Other inhibitors (2 and 6) manifested a similar relationship between enzyme activity and enzyme concentration. The equilibrium constant for inhibitor binding, $K_{\mathrm{I}}$ was obtained from the values at the intersection of three lines from Dixon plots as shown in Fig. 2C-E. The $K_{\mathrm{I}}$ values of inhibitors are presented in Table 1 . All the measurements were 

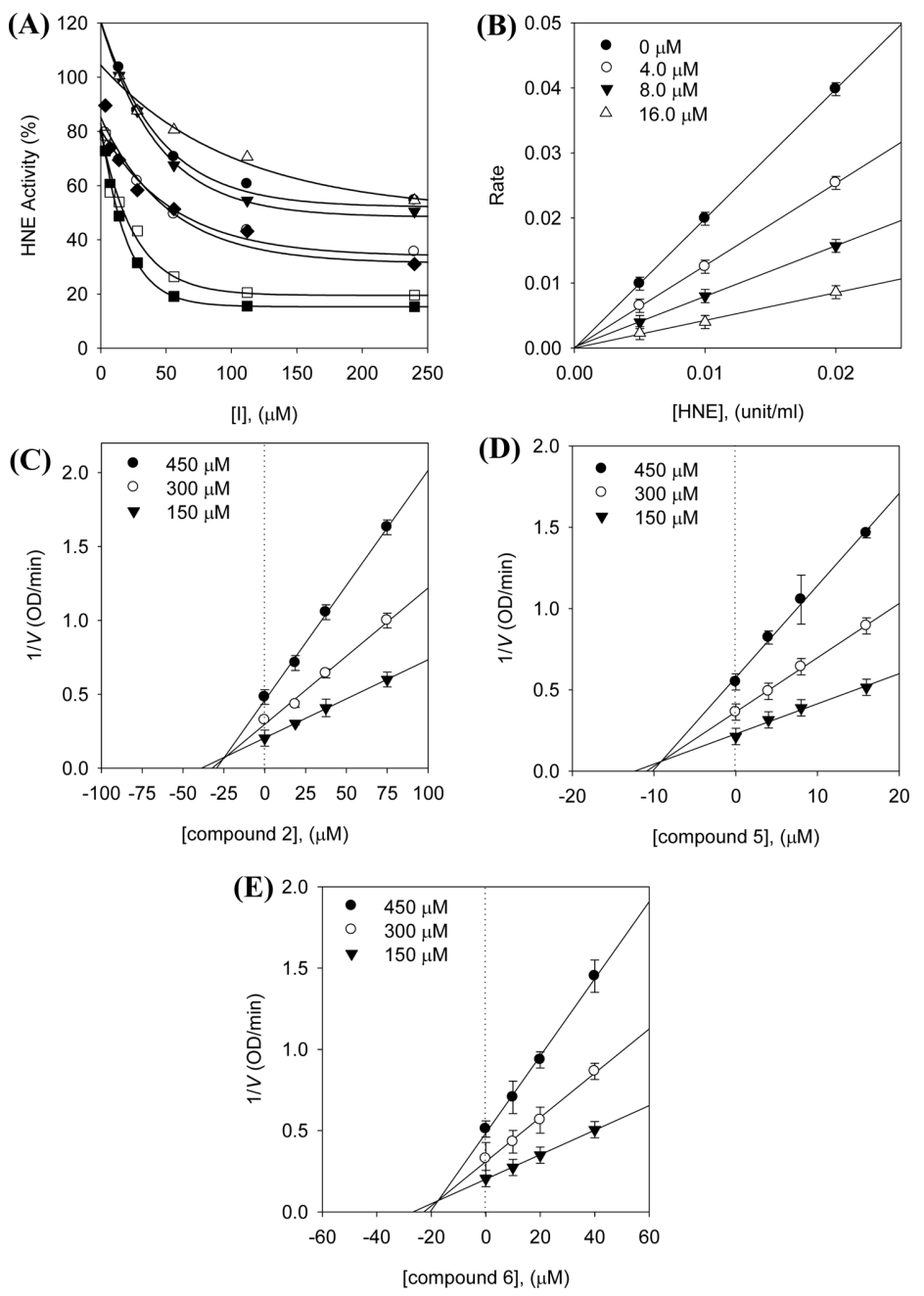

Fig. 2 (A) Effects of isolated compounds $\mathbf{1 - 6}$ on HNE for the hydrolysis of Suc-Ala-Ala-Ala- $p$ NA ( $>$ compound 1; $\bigcirc$ compound 2; $\boldsymbol{\nabla}$ compound 3 ;

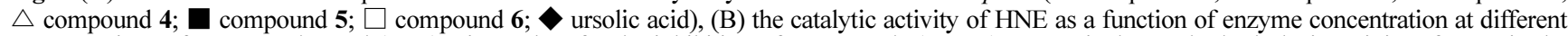
concentrations of compound $\mathbf{5}$ and $(\mathrm{C}-\mathrm{E})$ Dixon plots for the inhibition of compounds $(\mathbf{2}, \mathbf{5}, \mathbf{6})$, respectively, on the hydrolysis activity of HNE in the presence of different concentrations of substrate.

Table 1 Inhibitory effect of isolated compounds 1-6 on human neutrophil elastase

\begin{tabular}{|c|c|c|c|c|}
\hline Compound & $\mathrm{IC}_{50}{ }^{\mathrm{a}}$ value $(\mu \mathrm{M})$ & Inhibition mode & $K_{\mathrm{I}}(\mu \mathrm{M})$ & $K_{\mathrm{IS}}(\mu \mathrm{M})$ \\
\hline 1 & $>200$ & $\mathrm{NT}^{\mathrm{b}}$ & - & - \\
\hline 2 & $51.0 \pm 0.4$ & Mixed type I & $34.0 \pm 0.8$ & $87.5 \pm 0.7$ \\
\hline 3 & $>200$ & NT & - & - \\
\hline 4 & $>200$ & NT & - & - \\
\hline 5 & $11.6 \pm 1.1$ & Mixed type I & $9.1 \pm 0.5$ & $18.8 \pm 0.6$ \\
\hline 6 & $20.7 \pm 0.9$ & Mixed type I & $13.0 \pm 0.2$ & $31.0 \pm 0.4$ \\
\hline Ursolic acid $^{\mathrm{c}}$ & $30.6 \pm 1.8$ & NT & - & - \\
\hline
\end{tabular}

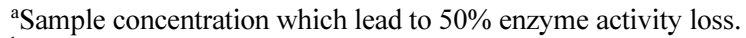

${ }^{\mathrm{b}} \mathrm{NT}$ is not tested. ${ }^{\mathrm{c} U r s o l i c}$ acid was used as a positive control.

made in triplicated

Enzyme kinetic analysis. The enzyme inhibition properties of the isolation inhibitors were modeled using double-reciprocal plots of Lineweaver-Burk and Dixon analysis. As shown in Fig. 3A-C, the inhibition kinetics analyzed by Lineweaver-Burk plots show that all compounds $(\mathbf{2}, \mathbf{5}$, and $\mathbf{6})$ are mixed-type inhibitors because increasing inhibitor concentration resulted in a family of lines which intersected at a nonzero point on both $\mathrm{x}$ - and $\mathrm{y}$-axes. Since the inhibition was mixed, this means that inhibitor has different affinities for the substrate bound and free enzyme. Thus we tried to analyze the respective inhibition constants for the two states. Type I is where inhibitor preferably binds to the free enzyme 

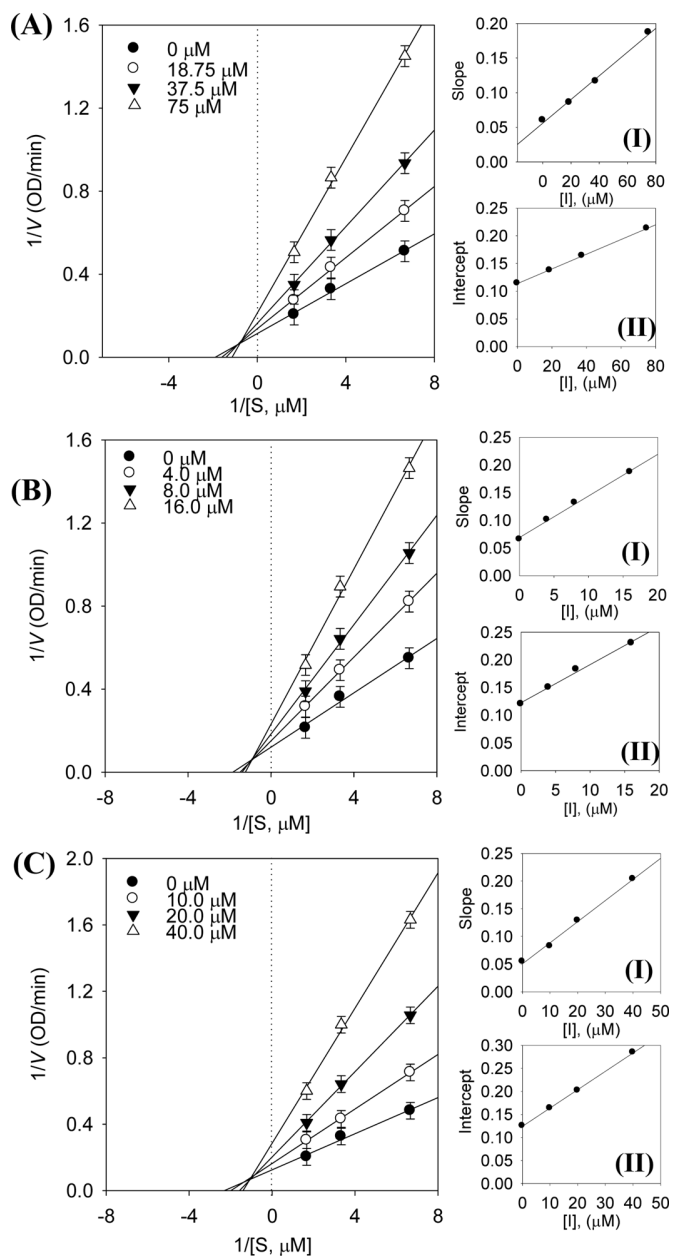

Fig. 3 (A-C) Kinetic assays of HNE inhibition by stylopine (2), spallidamine (5), and $\mathrm{N}$-trans-feruloyltyramine (6). Lineweaver-Burk plots were constructed for the inhibition of HNE by compounds $(\mathbf{2}, \mathbf{5}$ and 6). The plot is expressed as $1 /$ velocity versus $1 / \mathrm{HNE}$ (Unit/mL) with or without inhibitor. Insets (I) and (II) represent the secondary plot of the slope and the intercept of the straight lines versus concentration of compounds $(\mathbf{2}, \mathbf{5}$ and $\mathbf{6})$, respectively.

while Type II is where inhibitor preferably binds to the enzyme substrate complex. This analysis is carried out by varying both inhibitor and substrate concentration, as shown by Equations (1)(3). The equilibrium to free enzyme $\left(K_{\mathrm{I}}\right)$ and enzyme-substrate complex $\left(K_{\mathrm{IS}}\right)$ were obtained from secondary plots of $K_{\mathrm{m}} / V_{\max }$ and $1 / V_{\max }$ versus concentration of compounds $\mathbf{2 , 5}$, and $\mathbf{6}$, respectively. We thus established the following constants: compound 2, $K_{\mathrm{I}}=34.0 \mu \mathrm{M}$, and $K_{\mathrm{IS}}=87.5 \mu \mathrm{M}$; compound $5, K_{\mathrm{I}}=9.1 \mu \mathrm{M}$ and $K_{\mathrm{IS}}=17.8 \mu \mathrm{M}$; compound 6, $K_{\mathrm{I}}=13.0 \mu \mathrm{M}$ and $K_{\mathrm{IS}}=31.0 \mu \mathrm{M}$ (Fig. 3 insects). These data show that the affinity of the inhibitor for free enzyme is significantly stronger that the affinity of inhibitor for the enzyme-substrate complex. Thus, compound 2, 5, and $\mathbf{6}$ are mixed type I inhibitors (Roberts, 1977).

This study demonstrates that the methanol extract of $C$. majus L. show potent inhibitory activity toward human neutrophil elastase. Three compounds, (s)-stylopine (2), spallidamine (5), and $\mathrm{N}$-trans-feruloyltyramine (6), were the principal contributors to the HNE inhibition. The analysis of $K_{\mathrm{I}}$ and $K_{\mathrm{IS}}$ values proved that three inhibitors $(\mathbf{2}, \mathbf{5}$, and $\mathbf{6})$ had a reversible mixed type I behavior.

Acknowledgments This research was supported by a grant Next-Generation BioGreen 21 program (SSAC, NO.PJ01107001), Rural Development Administration, Republic of Korea, All students were supported by a scholarship from the BK21 plus program.

\section{References}

Barens J, Anderson LA, and Phillipson JD (2007) In Herbal Medicines: a guide for healthcare professional, (3rd ed). Pharmaceutical Press, London.

Barreto MC, Pinto RE, Arrabaca JD, and Pavao ML (2003) Inhibition of mouse liver respiration by Chelidonium majus isoquinoline alkaloids. Toxical Lett 146, 37.

Bode W, Meyer E, and Powers JC (1989) Human leukocyte and porcine pancreatic elastase: x-ray crystal structures, mechanism, substrate specificity, and mechanism-based inhibitors. Biochemistry 28, 1951-63.

Brice K, Marshall S, Horwitz, Dieter E, Jenne, Francis G et al. (2010) Neutrophil elastase, Proteinase 3, and Cathepsin G as therapeutic Targets in Human diseases. Pharmacol Rev 62, 726-59.

Chiari ME, Vera DMA, Palaciou SM, and Carpinella MC (2011) Tyrosinase inhibitory activity of a 6-isoprenoid-substituted flavanone isolated from Dalea elegans. Bioorg Med Chem 19, 3474-82.

Cho KM, Yoo ID, and Kim WG (2006) 8-Hydroxydihydrochelerythrine and 8-Hydrosanguinarine with a potent acetylcholinesterase inhibitory activity from Chelidonium majus L. Biol Pharm Bull 29, 2317-20.

Colombo ML and Bosisio E (1996) Pharmacological activities of Chelidonium majus L. (Papaveraceae). Pharmacol Res 33, 127-34.

Crocetti L, Schepetkin IA, Cilibrizzi A, Graziano A, Vergelli C, Giomi D et al. (2013) Optimization of $N$-benzoylindazole derivatives as inhibitors of human neutrophil elastase. J Med Chem 56, 6259-72.

Johansson S, Goransson U, Lujiendijk T, Backlund A, Claeson P, Bohlin L et al. (2002) A neutrophil multitarget functional bioassay to detect antiinflammatory natural products. J Nat Prod 65, 32-41.

Kanada RM, Simionato JI, Arruda RF, Santin SMO, Souza MC, Silva CC et al. (2012) $N$-trans-feruloyltyramine and flavonol glycosides from the leaves of Solanum sordidum. Rev Bras Farmacogn 22, 502-6.

Koul S, Razdan TK, Andotra CS, Kalla AK, Koul S, and Taneja SC (2002) Benzophenanthridine Alkaloids from Corydalis flabellate. Planta Med 68, 262-5.

Lenfield J, Kroutil M, Marsalek E, Salvok J, Preininger V, and Simanek V (1981) Antiinflammatory activity of quaternary benzophenanthridine alkaloids from Chelidonium majus. Planta Med 43, 161-5.

Ma WG, Fukush Y, and Tahara S (1999) Fungitoxic alkaloids from Hokkaido Corydalis species. Fitoterapia 70, 258-65.

Roberts DV (1977) In Enzyme kinetics, Cambridge University Press, UK.

Siedle B, Hrenn A, and Merfort I (2007) Inhibition of human neutrophil elastase by pentacyclic triterpenes, Planta Med 73, 401-20.

Zhang JP, Chen QX, Song KK, and Xie JJ (2006) Inhibitory effects of salicylic acid family compounds on the diphenolase activity of mushroom tyrosinase. Food Chem 95, 579-84. 